\title{
EFFECTS OF THYROID ON CREATINE METABOLISM WITH A DISCUSSION OF THE MECHANISM OF STORAGE AND EXCRETION OF CREATINE BODIES ${ }^{1}$
}

\author{
By LAWSON WILKINS AND WALTER FLEISCHMANN \\ (From the Department of Pediatrics, Johns Hopkins University School of Medicine, and the \\ Harriet Lane Home of the Johns Hopkins Hospital, Baltimore)
}

(Received for publication October 15, 1945)

The vast literature which has accumulated on the metabolism of creatine has been reviewed in a number of monographs ( 1 to 4 ). The discovery of phosphocreatine in muscle $(5,6)$ was followed by extensive work on the enzyme system controlling the creatine-phosphocreatine cycle and the rôle of this cycle in muscular contraction $(7,8)$. The synthesis of creatine from its precursors has recently been elucidated using isotopes $(9,10)$ and experiments on isolated tissues (11). It has been demonstrated that administration of androgens having a methyl group in the 17-position leads to an outpouring of creatine into the urine, presumably through an increased synthesis of creatine (12 to 14$)$.

In spite of all this work, the mechanism by which various physiological and pathological conditions influence the excretion of creatine and creatinine is still little understood. The elucidation of these problems depends on the one hand on the study of the synthesis of creatine from its precursors, and on the other hand, upon an understanding of the factors which govern the storage of creatine and phosphocreatine in the muscles, and the liberation and excretion of creatine and creatinine in the urine. The effects of thyroid on the excretion of creatine are so marked that they present an opportunity to study these questions. In this paper we shall survey briefly knowledge which has accumulated on the relationship of thyroid to creatine metabolism and add to it observations which we have made. We shall then discuss the bearing of these findings upon the mechanism of the storage and excretion of creatine and creatinine.

1 This work was made possible by a grant from the Commonwealth Fund for the study of endocrine problems in childhood, supplemented by the John Howland Memorial Fund. The contents of this paper have been reported from time to time in the minutes of the Conference on the Metabolic Aspects of Convalescence, sponsored by the Josiah Macy, Jr. Foundation.
Excretion of creatine and creatinine in hyperthyroidism and hypothyroidism

The relation of thyroid to the excretion of creatine was first pointed out in 1908 by Shaffer (15) who found increased creatine and decreased creatinine excretion in Graves disease. It is now generally recognized that the output of creatine is increased in hyperthyroidism (16 to 18 ), and that the physiological creatinuria of childhood is absent or decreased in hypothyroid children (19 to $23,31)$.

Less attention has been paid to the effect of thyroid on the output of creatinine since the changes involve a relatively small percentage of the total output of this substance. Some writers consider these changes as insignificant (16). However, the original observation of Shaffer that the output of creatinine is markedly decreased in hyperthyroidism has been confirmed by others $(18,24)$. Wang (4) found an average daily urine creatinine excretion of $11.7 \mathrm{mgm}$. per $\mathrm{kgm}$. in females with thyrotoxicosis, compared to a normal range of 14 to $22 \mathrm{mgm}$. per $\mathrm{kgm}$. He did not demonstrate any alteration in the creatinine output in two cases of myxedema studied.

Although the total output of combined creatine + creatinine is of great importance in the study of the mechanism of storage and excretion, most writers have paid little attention to this. Eimer (25) reported total daily creatine + creatinine excretion of 11.6 to $17.7 \mathrm{mgm}$. per $\mathrm{kgm}$. in women suffering from Graves disease, as compared to an excretion of from 18 to $22 \mathrm{mgm}$. per $\mathrm{kgm}$. in normal women. Our own observations agree with those of most workers. However, a comparison of the coefficients of creatinine and of total creatine + creatinine in groups of hyperthyroid and hypothyroid patients with those of normal patients, does not give a true comparison of the output of such patients in relation to the actual muscle mass. The coefficients based on total body weight mav be 
misleading, since in the thin hyperthyroid patient the relative amount of muscle may be increased due to a depletion of fat, and in the hypothyroid patient the proportion of muscle is decreased because of the large amount of myxedematous fluid. More reliable information may be obtained by studying the excretion of a hyperthyroid or a hypothyroid patient before treatment and again after he has been adjusted through treatment to a comparatively normal state. We shall present such data in subsequent sections, but our general conclusions on the subject may be presented at this point.

In relation to the normal, the creatine output is increased in hyperthyroidism, decreased in hypothyroidism.

The creatinine output is decreased in hyperthyroidism and increased in hypothyroidism.

The total creatine + creatinine is relatively little affected; in hyperthyroidism there may be a significant decrease in some cases; in hypothyroidism the total output differs little from the normal but may be slightly increased.

\section{Muscle creatine and phosphocreatine in hyper- thyroidism and hypothyroidism}

In thyrotoxic rats a significant decrease of the creatine content of the striated muscle (26) and a decrease of both phosphocreatine and creatine in heart muscle (27) has been demonstrated. Wang (4), using improved methods, studied both creatine and phosphocreatine in rabbits. His results are shown in Table I.

Although the statistical significance of Wang's data becomes evident only if the thyroxinized and thyroidectomized rabbits are compared, his observations suggest that both creatine and phosphocreatine are decreased in hyperthyroidism and increased in hypothyroidism. It is probable that
TABLE I

Effects of thyroid on muscle creatine of rabbits (Wang)

\begin{tabular}{l|c|c|c|c}
\hline \hline & $\begin{array}{c}\text { No. of } \\
\text { animals }\end{array}$ & $\begin{array}{c}\text { Free } \\
\text { creatine }\end{array}$ & $\begin{array}{c}\text { Phospho- } \\
\text { creatine }\end{array}$ & $\begin{array}{c}\text { Total } \\
\text { creatine }\end{array}$ \\
\cline { 2 - 4 } & 12 & $211 \pm 25$ & $247 \pm 18$ & $458 \pm 26$ \\
$\begin{array}{l}\text { Normal rabbits } \\
\text { Thyrotoxic rabbits }\end{array}$ & 12 & $205 \pm 33$ & $210 \pm 13$ & $415 \pm 30$ \\
$\begin{array}{l}\text { Thyroidectomized } \\
\text { rabbits }\end{array}$ & 5 & $237 \pm 30$ & $269 \pm 11$ & $505 \pm 25$ \\
\hline
\end{tabular}

the differences would have been more striking if allowance had been made for the fact that muscle tissues retain fluid in myxedema and are depleted of fluid and fat in hyperthyroidism.

\section{Treatment of thyrotoxic patients with iodine or with thiouracil}

Wang studied 23 females with thyrotoxicosis who were treated with iodine for periods of 15 to 55 days. He found in most instances a decrease in the creatine output, but states that the creatinine excretion was not altered. In reviewing these cases it appears that most did not have complete remission with iodine, the B.M.R. remaining + 20 to +85 per cent. If we select the three cases studied after operation (No. 48 to 50 ), and one treated with iodine with a reduction of the B.M.R. to +10 per cent (No. 59), we note the following results (Table II).

In these four cases the creatinine output increased and the creatine diminished as the thyrotoxicosis improved. In two of the cases the total creatine + creatinine output decreased and in the other two it increased. A survey of the data reported in the literature shows that in thyrotoxic patients treated with iodine $(16,28)$ or with thiouracil $(29,30)$ the rise in creatinine excretion is not as consistent as the drop in creatine excretion.

TABLE II

Effect of treatment on the creatine-creatinine excretion of thyrotoxic patients (Wang)

\begin{tabular}{|c|c|c|c|c|c|c|c|c|c|}
\hline & \multicolumn{4}{|c|}{ Before treatment (first 3 days) } & \multicolumn{5}{|c|}{ After treatment } \\
\hline & B.M.R. & Creatine & Creatinine & Total & Treatment & B.M.R. & Creatine & Creatinine & Total \\
\hline $\begin{array}{l}\text { Case No. } 48 \\
\text { Case No. } 49 \\
\text { Case No. } 50 \\
\text { Case No. } 59\end{array}$ & $\begin{array}{l}\text { per cent } \\
+62 \\
+47 \\
+50 \\
+52\end{array}$ & $\begin{array}{l}m g m . \\
547 \\
475 \\
152 \\
117\end{array}$ & $\begin{array}{l}\text { mgm. } \\
514 \\
732 \\
735 \\
647\end{array}$ & $\begin{array}{r}m g m . \\
1061 \\
1207 \\
887 \\
761\end{array}$ & $\begin{array}{l}\text { Operation } \\
\text { Operation } \\
\text { Operation } \\
\text { Iodine }\end{array}$ & $\begin{array}{c}\text { per cent } \\
+34 \\
+39 \\
-5 \\
+10\end{array}$ & $\begin{array}{c}m g m . \\
85 \\
52 \\
2 \\
30\end{array}$ & $\begin{array}{l}\text { mgm. } \\
552 \\
803 \\
832 \\
957\end{array}$ & $\begin{array}{r}m g m . \\
637 \\
855 \\
834 \\
987\end{array}$ \\
\hline
\end{tabular}




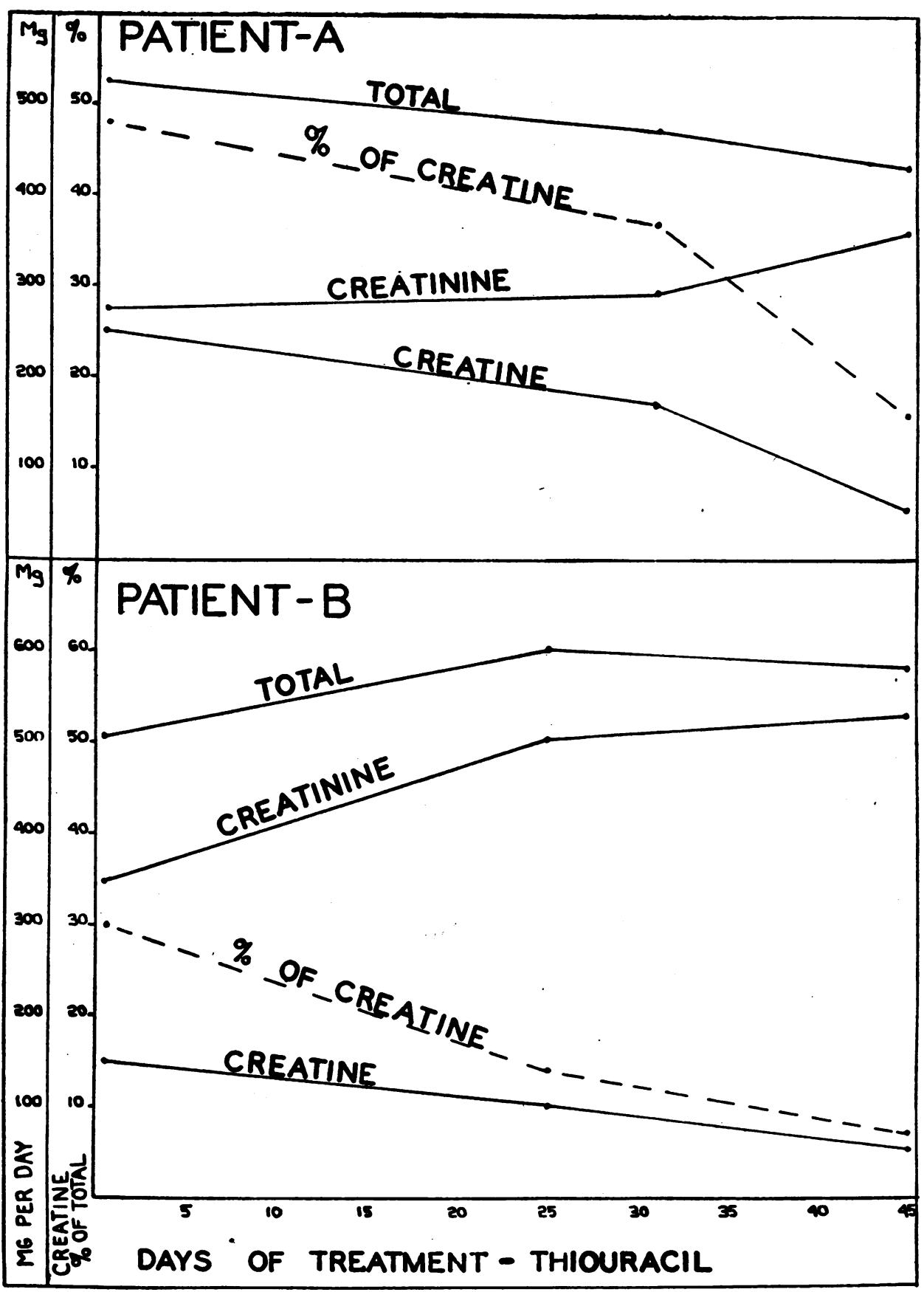

Fig. 1. Treatment of Thyrotoxicosis with Thiouracil

$$
\text { B.M.R. }
$$

Cholesterol

Patient A: Jesse H. 11 yrs. Before treatment +43 to +47 per cent 155 mgm. per cent After treatment +44 to $+45 \quad 130$

$\begin{array}{llrr}\text { Patient B: Joyce G. } 13 \text { yrs. } & \begin{array}{l}\text { Before treatment }+24 \text { to }+35 \\ \text { After treatment }+7 \text { to } 0\end{array}\end{array}$

The line designated "per cent of creatine" indicates the ratio of creatine : creatine + creatinine. 
Our own experience with thiouracil therapy in children has been limited to two cases. In both of these cases when a creatine-free diet was given treatment caused a decrease in the output of creatine and an increase of creatinine. The total creatine + creatinine was decreased in one case and increased slightly in the other. These results are illustrated graphically in Figure 1.

\section{Treatment of hypothyroidism with desiccated thyroid}

The effects of thyroid are shown most clearly when an athyrotic patient is first given thyroid therapy and the output of creatine and creatinine is measured daily for periods of 40 to 60 days. In previous papers we published data on the treatment of hypothyroid children (31) and subsequently we

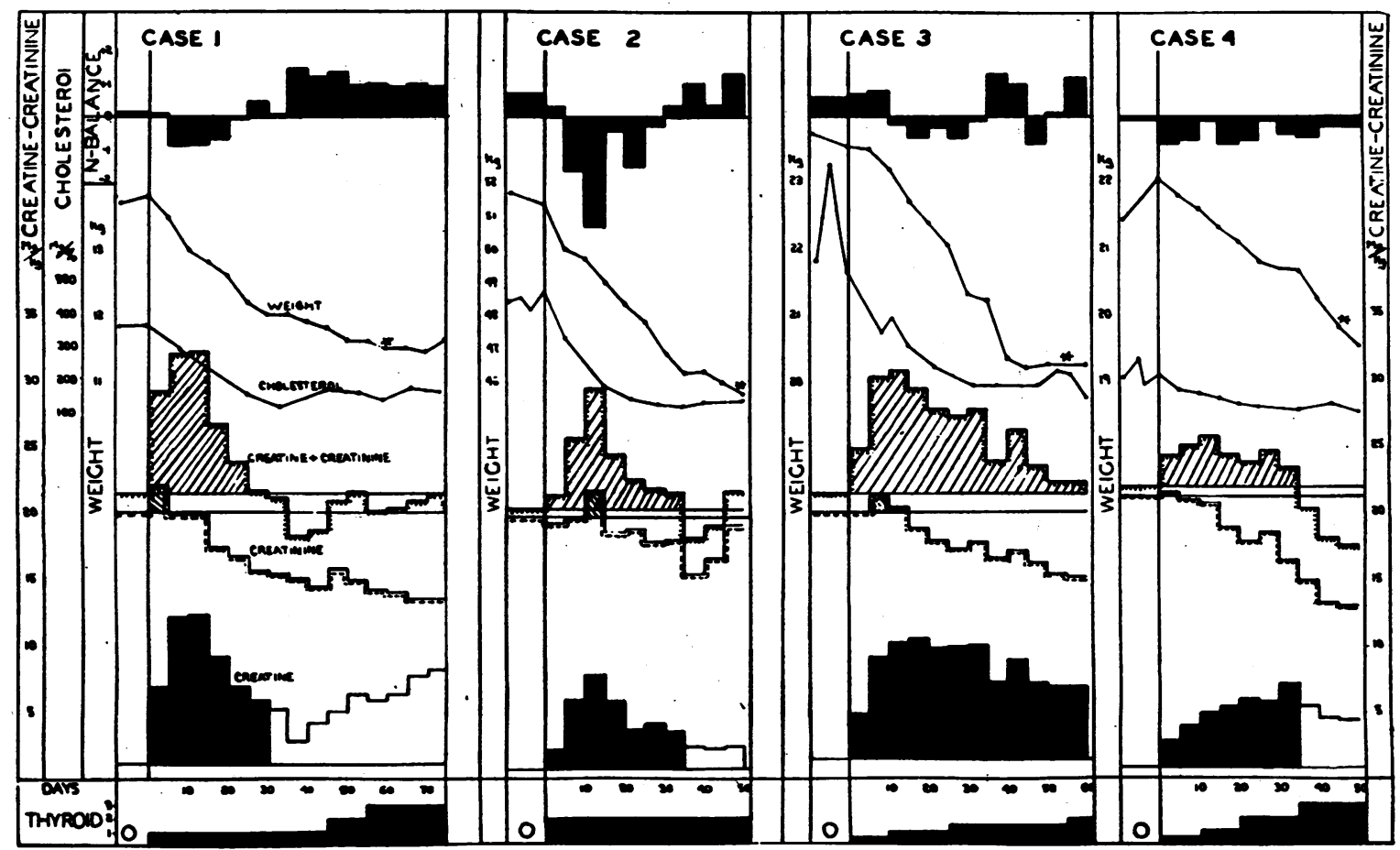

Fig. 2. Treatment of Hypothyroid Patients with Thyroid

Case 1. Ronnie Z. Age 4 yrs. 4 mos. Bone age 3 mos. Height-age 11/2 yrs. Previously untreated.

Case 2. Gertrude S. Age 27 yrs. Cretin-mentally defective. Untreated until she was 22 yrs., then treated intermittently. No treatment for 6 months prior to study.

Case 3. Price R. Age 14 yrs. Bone age 5 yrs. Height-age $5 \%$ yrs. Previously untreated.

Case 4. Samuel A. Age 101/2 yrs. Bone age 3 yrs. Height-age 4\% yrs. Previously untreated.

In each case the output of creatine, creatinine and total is shown for an average of 10 days without treatment. The subsequent changes in excretion under treatment are shown as averages of 5-day periods. During the first phase of treatment the excretion of creatine + creatinine was elevated above the pretreatment level. The total creatine + creatinine lost is indicated by the shaded areas. The increase in the output of creatine during the corresponding period is shown by the black area. Following the first phase of treatment the output of creatine + creatinine was reduced to or slightly below the pretreatment level, but the creatine was relatively increased and the creatinine decreased. The nitrogen balances shown at the top of the charts indicate that there were small deficits during the first phase of treatment.

* Indicates weight used in calculating creatine and creatinine coefficients throughout experiment. The weight was selected at the end of the treatment period because this gives a better index of the tissue mass than the weight before or during treatment. The reason for this is that there are excess fluid stores in the myxedematous state. The marked decrease in weight during thyroid treatment is due almost entirely to the loss of body fluids and not to the loss of tissue proteins. Nitrogen balance studies carried out simultaneously showed that during the first 20 to 30 days of treatment there was only a slight loss of body protein and that after this there was a positive $\mathbf{N}$-balance. 


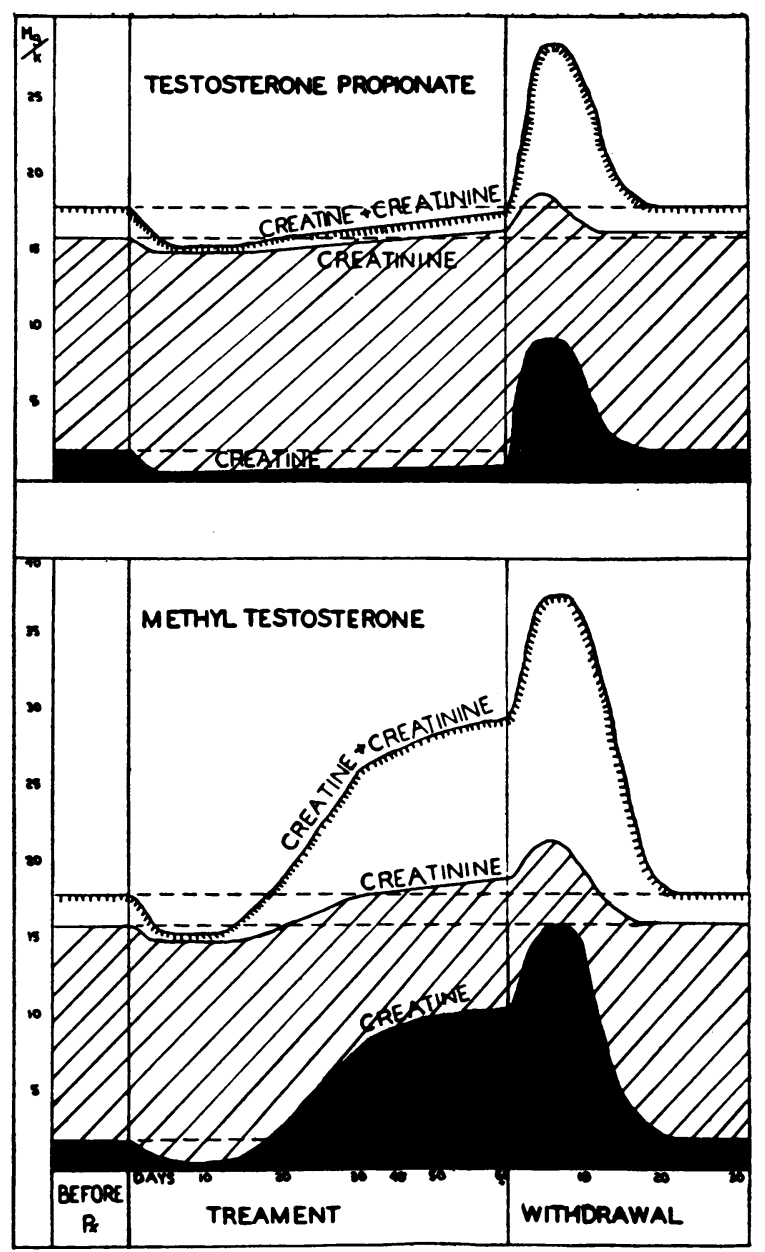

Fig. 3. Effects of Testosterone Propionate and Methyl Testosterone on Patients Who Are Not HYPOTHYROID

These curves represent averages. There are wide variations of the levels in individual cases (13).

contrasted the type of curve observed with that found when patients are treated with methyl testosterone (13). (Compare Figures 2 and 3). Other workers $(32,21)$ recorded similar effects from thyroid medication.

In Figure 2 we have recorded new observations made on four hypothyroid patients receiving diets containing less than $30 \mathrm{mgm}$. of creatine daily during the first 50 to 70 days of thyroid medication. The essential similarity of these charts is apparent in spite of minor variations which may depend upon the intensity of treatment and differences in the patients. The effects of treatment are perhaps illustrated best in cases 1 and 2, for which data are given in Table III.
In case 1 the output of total creatine + creatinine increased abruptly on the administration of thyroid, rising from a level of $21.6 \mathrm{mgm}$. per $\mathrm{kgm}$. to a peak of $32.3 \mathrm{mgm}$. per $\mathrm{kgm}$. between the $6 \mathrm{th}$ and 15th days. The excretion then decreased until it reached the pretreatment level by the 30th day. After this it remained at or slightly below the level which had existed during the hypothyroid state in spite of subsequent increase in the dose of thyroid.

The excretion of creatine rose from $1.3 \mathrm{mgm}$. per $\mathrm{kgm}$. to a peak of $12.3 \mathrm{mgm}$. per $\mathrm{kgm}$. between the 6 th and 15 th day. By the 30 th day it had decreased to $5.2 \mathrm{mgm}$. per $\mathrm{kgm}$. After this 
TABLE III

Effect of treatment of hypothyroid patients

\begin{tabular}{|c|c|c|c|c|c|c|c|c|}
\hline \multirow{2}{*}{$\begin{array}{c}\text { Days of } \\
\text { treatment }\end{array}$} & \multicolumn{2}{|c|}{ Creatinine } & \multicolumn{2}{|c|}{ Creatine } & \multicolumn{2}{|c|}{ Total } & \multirow{2}{*}{$\begin{array}{c}\begin{array}{c}\text { Ratio } \\
\text { Crea- } \\
\text { tinel } \\
\text { Total }\end{array} \\
\begin{array}{c}\text { per } \\
\text { cent }\end{array}\end{array}$} & \multirow{2}{*}{$\begin{array}{c}\begin{array}{c}\text { Thyroid } \\
\text { dose }\end{array} \\
m g m .\end{array}$} \\
\hline & mgm. & $\begin{array}{c}\underset{\text { per }}{\text { per }} \\
\text { kgm.* }\end{array}$ & mgm. & $\begin{array}{c}\text { mgm. } \\
\text { per } \\
\text { kgm. }\end{array}$ & $m g m$. & $\begin{array}{c}\text { mgm. } \\
\text { per } \\
\text { kgm. }\end{array}$ & & \\
\hline \multicolumn{9}{|c|}{ Case 1} \\
\hline $\begin{array}{l}\text { Con trol } \\
1 \text { to } 5 \\
6 \text { to } 10 \\
11 \text { to } 15 \\
16 \text { to } 20 \\
21 \text { to } 25 \\
26 \text { to } 30 \\
31 \text { to } 35 \\
36 \text { to } 40 \\
41 \text { to } 45 \\
46 \text { to } 50 \\
51 \text { to } 55 \\
56 \text { to } 60 \\
61 \text { to } 65 \\
66 \text { to } 70\end{array}$ & \begin{tabular}{|l|}
233 \\
255 \\
231 \\
230 \\
201 \\
193 \\
182 \\
179 \\
176 \\
167 \\
183 \\
173 \\
164 \\
163 \\
156
\end{tabular} & $\begin{array}{l}20.3 \\
22.2 \\
20.0 \\
20.0 \\
17.5 \\
16.8 \\
15.8 \\
15.8 \\
15.3 \\
14.5 \\
15.9 \\
15.0 \\
14.3 \\
14.2 \\
13.5\end{array}$ & $\begin{array}{r}15 \\
79 \\
139 \\
141 \\
106 \\
82 \\
69 \\
59 \\
33 \\
50 \\
60 \\
74 \\
71 \\
74 \\
86\end{array}$ & $\begin{array}{r}1.3 \\
7.0 \\
12.2 \\
12.3 \\
9.2 \\
7.1 \\
6.0 \\
5.2 \\
2.9 \\
4.3 \\
5.2 \\
6.5 \\
6.1 \\
6.4 \\
7.5\end{array}$ & $\begin{array}{l}248 \\
334 \\
370 \\
371 \\
307 \\
275 \\
251 \\
238 \\
209 \\
217 \\
243 \\
247 \\
235 \\
237 \\
242\end{array}$ & $\begin{array}{l}21.6 \\
29.2 \\
32.2 \\
32.3 \\
26.7 \\
23.9 \\
21.8 \\
20.7 \\
18.2 \\
18.8 \\
21.1 \\
21.5 \\
20.4 \\
20.6 \\
21.0\end{array}$ & $\begin{array}{l}6 \\
24 \\
38 \\
38 \\
34 \\
30 \\
27 \\
25 \\
16 \\
21 \\
25 \\
30 \\
30 \\
31 \\
36\end{array}$ & $\begin{array}{r}0 \\
64 \\
64 \\
64 \\
64 \\
64 \\
64 \\
64 \\
64 \\
64 \\
128 \\
128 \\
192 \\
192 \\
192\end{array}$ \\
\hline
\end{tabular}

Case 2

\begin{tabular}{c|r|r|r|r|r|r|r|r}
\hline Control & 885 & 19.8 & 37 & 0.7 & 922 & 20.5 & 4 & 0 \\
1 to 5 & 861 & 19.1 & 98 & 2.2 & 959 & 21.3 & 10 & 128 \\
6 to 10 & 882 & 19.6 & 273 & 6.1 & 1155 & 25.7 & 24 & 128 \\
11 to 15 & 974 & 21.6 & 352 & 7.9 & 1326 & 29.5 & 27 & 128 \\
16 to 20 & 831 & 18.5 & 266 & 5.9 & 1097 & 24.4 & 24 & 128 \\
21 to 25 & 848 & 18.8 & 168 & 3.8 & 1016 & 22.6 & 17 & 128 \\
26 to 30 & 805 & 17.9 & 181 & 4.2 & 986 & 21.9 & 19 & 128 \\
31 to 35 & 811 & 18.0 & 169 & 3.6 & 980 & 21.6 & 17 & 128 \\
36 to 40 & 693 & 15.4 & 122 & 2.7 & 815 & 18.1 & 15 & 128 \\
41 to 45 & 747 & 16.6 & 112 & 2.5 & 859 & 19.1 & 13 & 128 \\
46 to 50 & 868 & 19.1 & 111 & 2.6 & 979 & 21.7 & 12 & 128 \\
\hline
\end{tabular}

* In case 1 - the coefficients were calculated for weight of $11.5 \mathrm{kgm}$. throughout experiment.

In case 2 -calculations were for weight of $45.0 \mathrm{kgm}$.

the output fluctuated between 2.9 and $5.2 \mathrm{mgm}$. per kgm. during treatment with $64 \mathrm{mgm}$. of thyroid. When the dosage of thyroid was increased progressively up to $192 \mathrm{mgm}$. daily, the creatine output increased up to $7.5 \mathrm{mgm}$. per $\mathrm{kgm}$.

The excretion of creatinine showed decided changes of a different sort. The ouput was slightly above the pretreatment level during the first 5 days. After the 15 th day it decreased progressively reaching a level of $13.5 \mathrm{mgm}$. per $\mathrm{kgm}$. compared to $20.3 \mathrm{mgm}$. per $\mathrm{kgm}$. before treatment.

It is apparent that the effects of thyroid treatment fall into two phases. In the first phase (in this case lasting 30 days) there was an output of total creatine + creatinine above the hypothyroid level. In the second phase, the total excretion was approximately at the same level as during the hypothyroid state or perhaps slightly below it. During this phase, however, the creatine excretion was considerably increased and the creatinine excretion decreased in relation to the hypothyroid levels. Before treatment, free creatine constituted 6 per cent of the total; after adjustment to a dose of $64 \mathrm{mgm}$. of thyroid, 16 to 21 per cent. Increasing the dose of thyroid up to $192 \mathrm{mgm}$. caused the proportion of creatine to increase to 36 per cent, although the total output of creatine + creatinine was not affected.

Although the most obvious explanation of the temporary increase in the total creatine + creatinine output which occurs during the first phase of treatment, is an outpouring of stores of creatine from the muscles, it is necessary to consider other possible explanations. One other explanation might be that the patient loses his original sensitivity to thyroid and fails to respond after a time. This is unlikely, because in all cases the serum cholesterol remained at a low level, the B.M.R. continued to rise and clinical improvement progressed. The weight did not increase after the total creatine + creatinine excretion returned to the hypothyroid level. Another explanation might be that thyroid temporarily causes an increased synthesis of creatine. We shall disprove this in our further discussion by observations indicating that thyroid does not influence the synthesis of creatine caused by methyl testosterone. If then we admit that there is a release of creatine stores during the first stage of treatment, the amount released can be calculated in case 1 as follows:

$$
\begin{array}{lcrr} 
& \begin{array}{c}
\text { Total } \\
\text { creatine } \\
\text { creatinine } \\
m g m .
\end{array} & \begin{array}{c}
\text { Creatine } \\
m g m .
\end{array} & \begin{array}{c}
\text { Creatinine } \\
m g m .
\end{array} \\
\begin{array}{l}
\text { Excretion during treatment } \\
\text { days 1 to 30 }
\end{array} & 9540 & 3080 & 6460 \\
\begin{array}{l}
\text { Excretion at pretreatment level } \\
\text { for 30 days }
\end{array} & 7440 & 450 & 6990 \\
\quad \text { Difference } & +\frac{6100}{210} & +\frac{630}{530} & -\frac{5}{530}
\end{array}
$$

The total creatine + creatinine lost from the body amounted to $2100 \mathrm{mgm}$. However, the creatine output was $2630 \mathrm{mgm}$. greater than would have occurred at the hypothyroid level of excretion. The difference of $530 \mathrm{mgm}$. is accounted for by a corresponding decrease in the output of creatinine. 
The amounts of stores lost from the body (shown in Figure 2 by the black or shaded areas) vary in different cases and are not in exact relation to the patient's weight. It is apparent that in each case the increase in the amount of creatine put out during this period was greater than that of total creatine + creatinine. This means that a portion of the creatinine output comes directly from the stores and the remainder is due to a decrease in the conversion of creatine into creatinine.
The effect of testoterone propionate and methyl testosterone on the creatine metabolism of normal and hypogonadal patients

In a previous paper (13) we have discussed the effects of androgens on creatine metabolism. As shown in Figure 3, testosterone propionate causes a decreased excretion of creatine and creatinine. This steroid brings about a rapid growth of muscle tissue for which creatine and phosphocreatine undoubtedly are needed. The decreased excretion

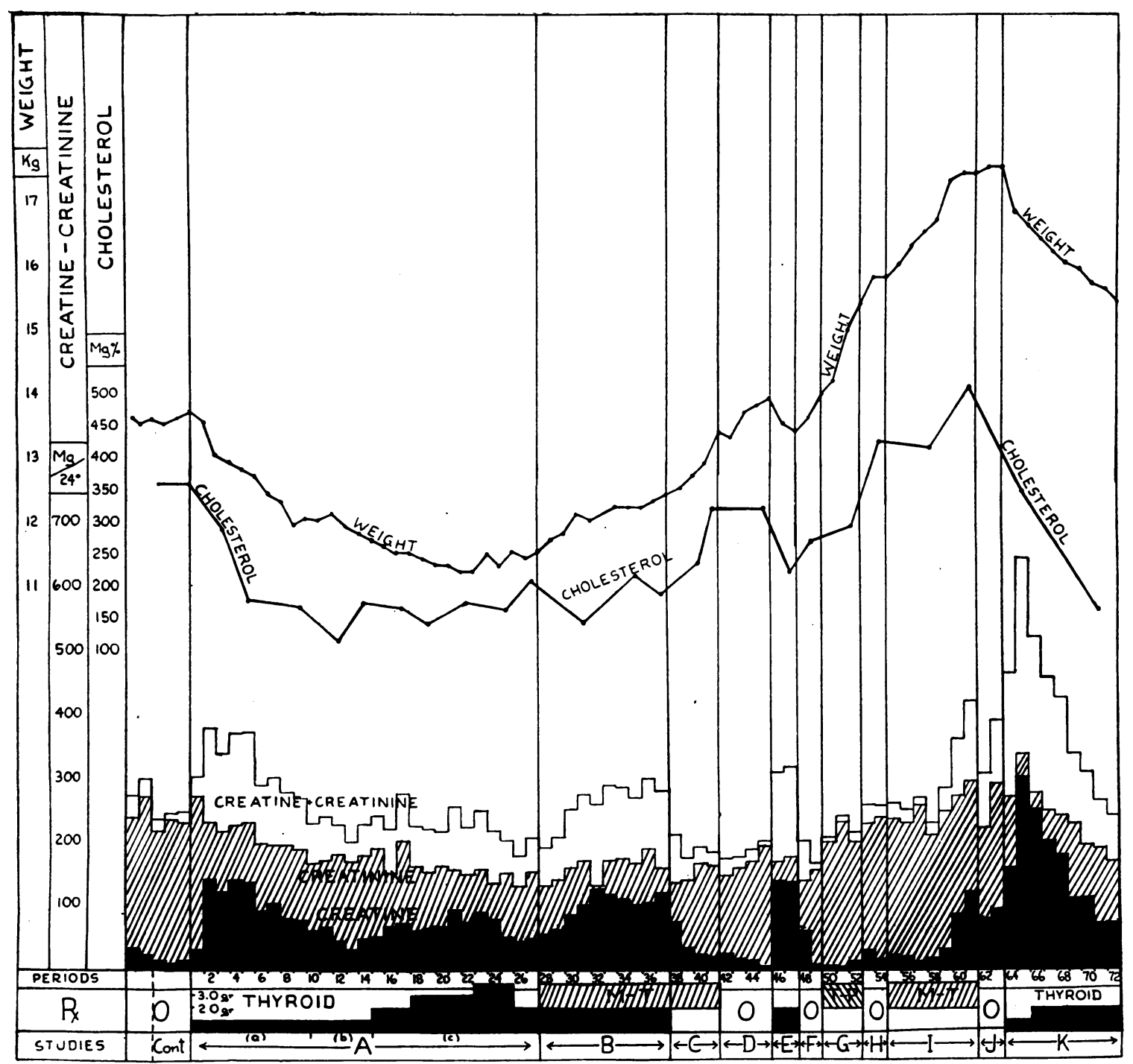

Fig. 4. Case 1. Hypothyroid Patient, Aged 41/2 Years. Effects of Thyroid, Methyl Testosterone, Testosterone Propionate and Combinations

Each column represents an average of a 5-day period 


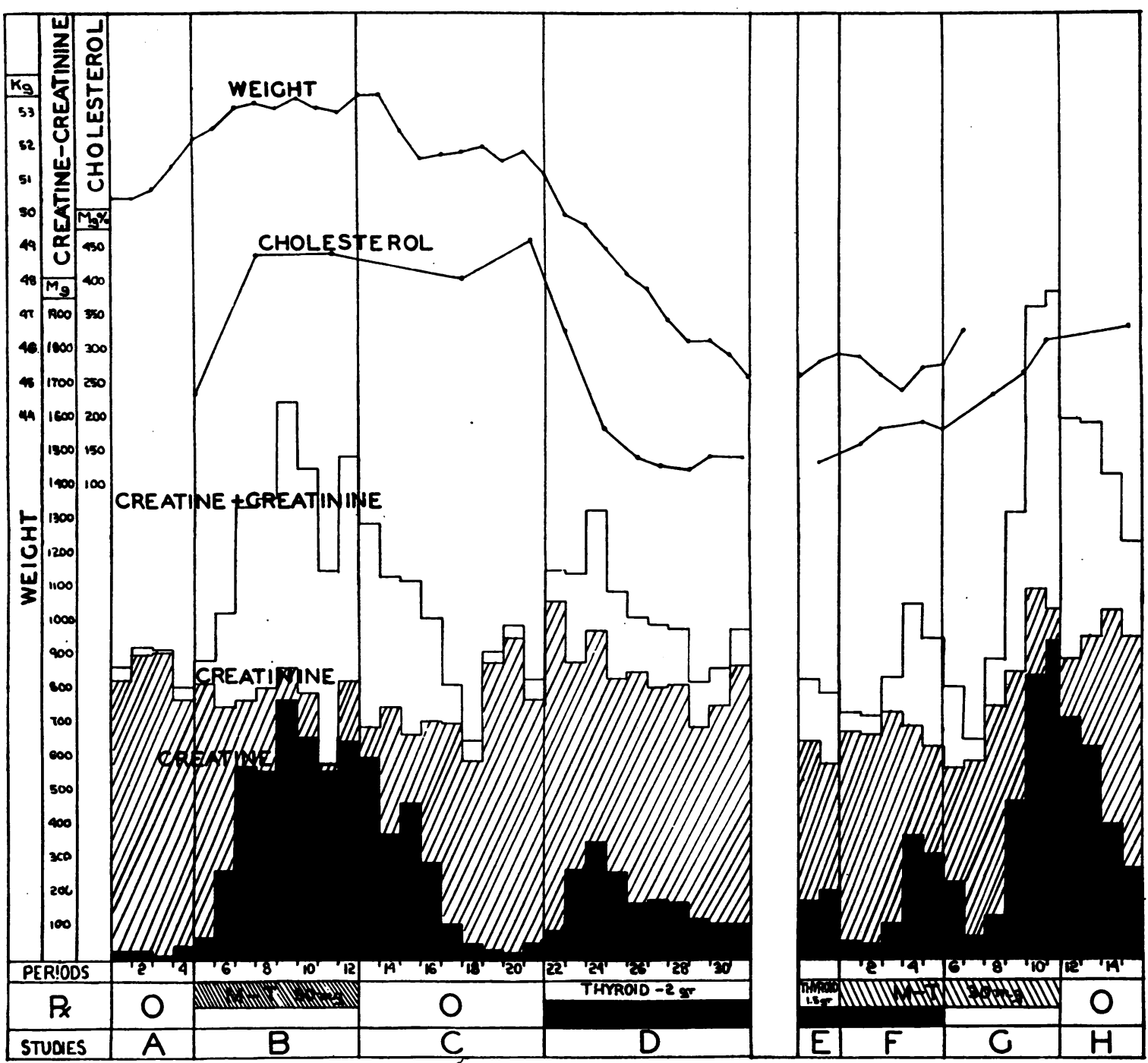

Fig. 5. Case 2. Hypothyroid Patient, Aged 27 Years. Effects of Thyroid Plus Methyl Testosterone and Combinations

Each column represents an average of a 5-day period

may be due to the fact that the increased needs of the body for creatine are not fulfilled by a corresponding increase of synthesis. The temporary loss of creatine and creatinine which occurs on discontinuing testosterone propionate resembles closely the negative nitrogen balance which has been observed on withdrawing androgenic therapy (34). Apparently when the stimulus to increased anabolism is withdrawn, a portion of the retained nitrogen which may be loosely bound is lost. It is possible that a portion of the creatine and phosphocreatine also is more loosely bound than the rest and is readily lost.
Methyl testosterone has a two-fold effect on creatine metabolism. It increases the need for creatine and phosphocreatine in building new muscle in the same way as does testosterone propionate, thus causing a slight temporary decrease in the excretion of creatine and creatinine. However, it also causes a marked increase in the rate of synthesis of creatine from its precursors, so that after 10 to 20 days the demands are exceeded, and increasing amounts appear in the urine. Discontinuing methyl testosterone causes a release of part of the stores as in the case of testosterone propionate. 


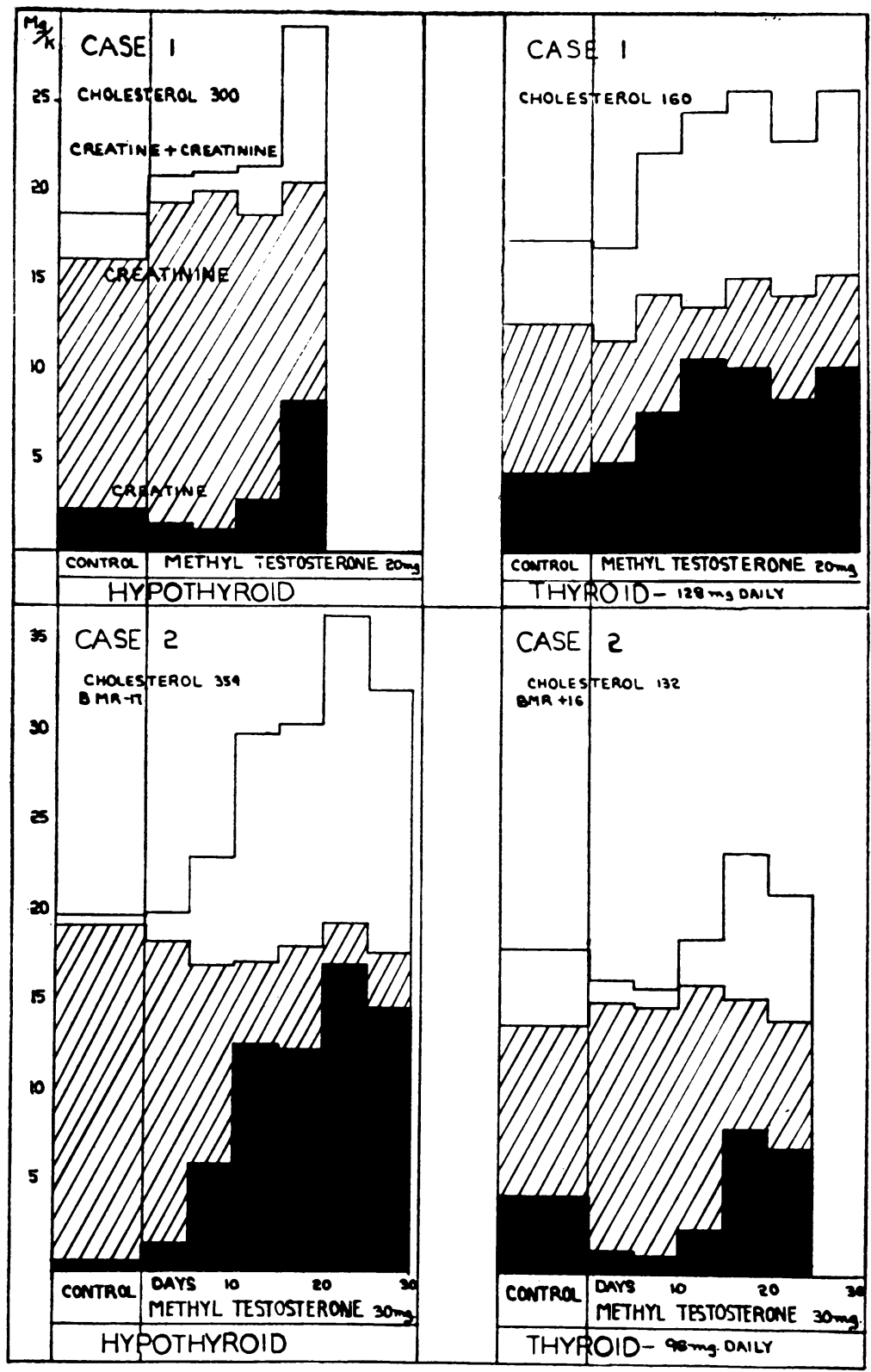

Fig. 6. Effects of Methyl Testosterone in Hypothyroid Patients When Untreated and When Corrected with Thyroid

Each column represents an average of a 5-day period.

Each of these hypothyroid patients was tested with methyl testosterone while untreated with thyroid and having a high serum cholesterol, and again when well adjusted on thyroid therapy and having a low serum cholesterol. In each case, whether treated or untreated, the excretion of creatine and creatine + creatinine increased although there were variations in the rapidity of the response. 
Action of methyl testosterone in hypothyroid patients

A number of experiments with methyl testosterone were made on two hypothyroid patients receiving a creatine-free diet, both while they were in the hypothyroid stage and while they were adjusted to an apparently normal condition by thyroid therapy. Patient 1 was a hypothyroid dwarfed boy of 4 years and 4 months who had a bone age of 3 months, and had never been treated previously. Patient 2 was a female cretin of 27 years who had been untreated until she was 22 years and was then treated intermittently. She was allowed to lapse into a hypothyroid state preparatory to the present studies. The complete studies are shown in Figures 4 and 5 . Several phases of these studies need special emphasis.

In Figure 6 are shown the effects of methyl testosterone when given to these two patients in the hypothyroid state in comparison with the effects exhibited by this steroid when these patients were adjusted to a comparatively normal condition

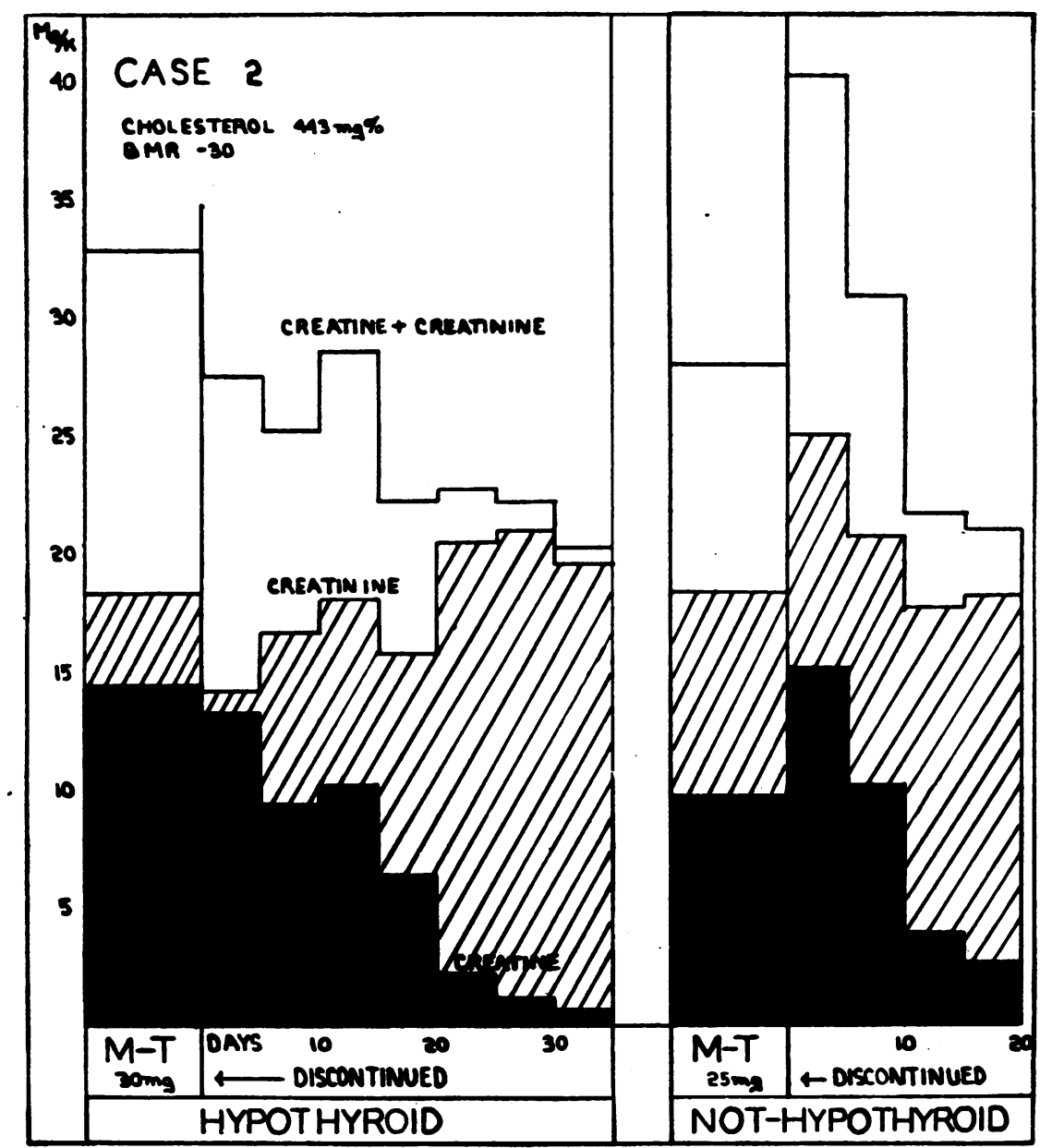

Fig. 7. Effects of Withdrawal of Methyl Testosterone in Hypothyroid Patient Compared to Effect in a Patient Not Hypothyroid

Each column represents an average of a 5-day period.

When this patient was given methyl testosterone while in a hypothyroid state the excretion of creatine and of creatine + creatinine was high. On discontinuing methyl testosterone, the output of creatine diminished promptly. Subsequently, when adjusted on thyroid medication, the withdrawal of thyroid was followed by a temporary increase in the excretion of both creatine and creatinine such as usually occurs in the normal individual. 
by thyroid medication. It is apparent that thyroid deficiency did not interfere with the synthesis and increased excretion of creatine which was brought about by methyl testosterone.

In Figure 7 is shown the effect of withdrawing medication with methyl testosterone from patient 2 while she was in the hypothyroid state, in contrast to the results observed. when methyl testosterone was discontinued in a hypogonadal patient who was not hypothyroid. There was no increase in the output of creatine or creatinine on withdrawing methyl testosterone during hypothyroidism. Instead, the excretion decreased rapidly to a low level. The same observation was made in patient 1.

In Figure 8 we have recorded other observations made on the same hypothyroid subjects. Patient 1 had been treated with thyroid for nearly three months when the experiment was begun. On a dose of $128 \mathrm{mgm}$. daily, the creatine output was

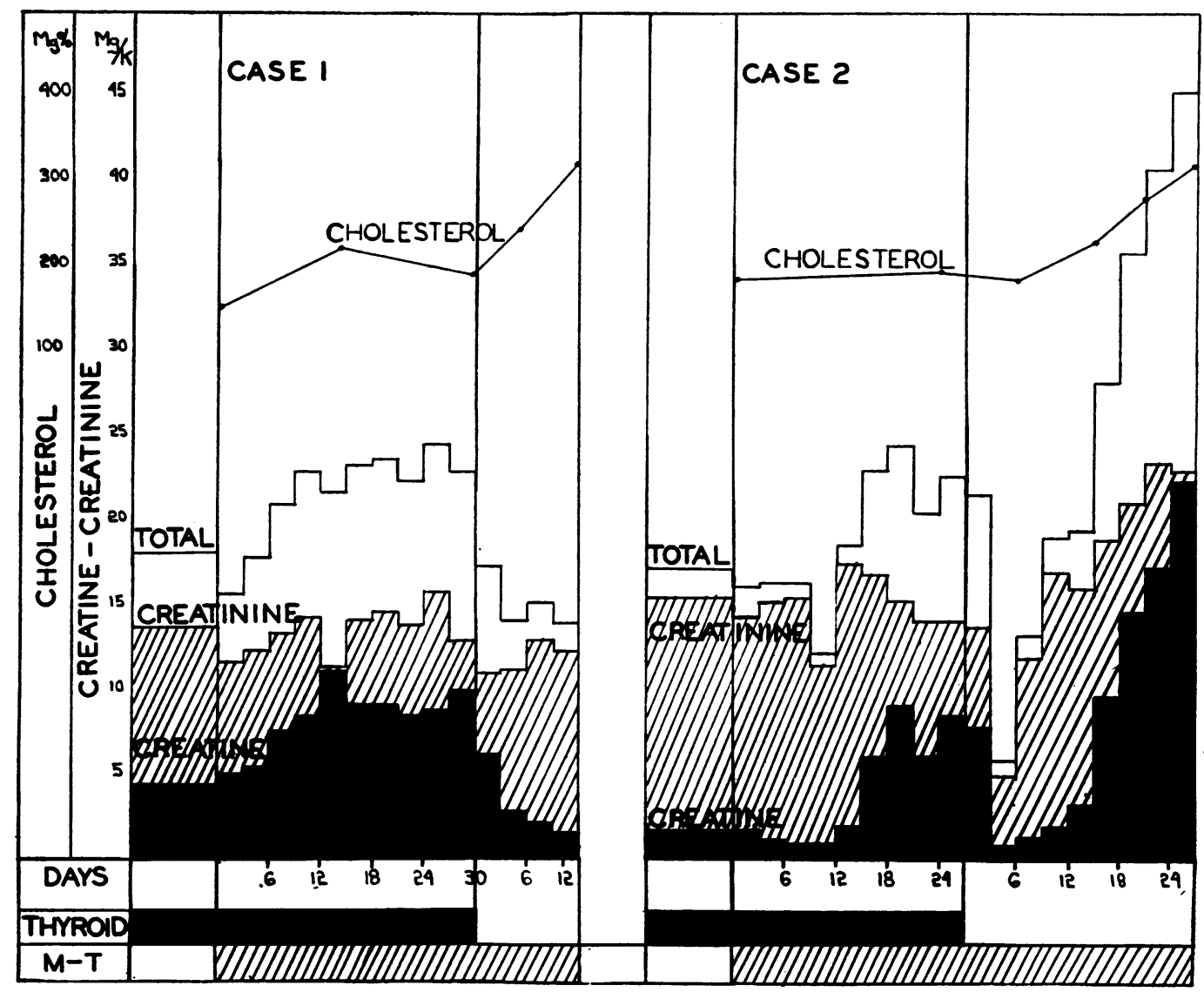

Fig. 8. Withdrawal of Thyroid During Treatment with Methyl Testosterone

Each column represents an average of a 3-day period.

Case 1. In first period, patient was well adjusted on $128 \mathrm{mgm}$. thyroid daily and had normal output of creatine and creatinine. The administration of $25 \mathrm{mgm}$. of methyl testosterone while thyroid was given caused increased output of creatine. After 30 days thyroid was stopped while methyl testosterone was continued. There was an immediate decrease in the output of creatine to a low level during the next 13 days. The serum cholesterol rose.

Case 2. Previous experiment repeated on another patient and continued longer. On the administration of methyl testosterone during thyroid treatment there was a latent period followed by an increasing output of creatine. After 26 days thyroid was discontinued but methyl testosterone continued. Withdrawal of thyroid caused an immediate decrease in the output of creatine for 13 days after which the excretion rose rapidly to higher levels than previously. There was a brief drop in the creatinine during the second 3-day period. 
fairly stabilized at $4.5 \mathrm{mgm}$. per $\mathrm{kgm}$. per day, creatinine $13.7 \mathrm{mgm}$. per $\mathrm{kgm}$. While he continued to receive the same dose of thyroid, he was given $20 \mathrm{mgm}$. of methyl testosterone daily for a period of 30 days. The output of creatine rose rapidly and at the end of the period had reached a plateau at 8.5 to $10.0 \mathrm{mgm}$. per $\mathrm{kgm}$., while the creatinine excretion was 13.0 to $15.8 \mathrm{mgm}$. per $\mathrm{kgm}$. At this time thyroid medication was discontinued but treatment with methyl testosterone was continued. The output of creatine dropped rapidly by the second day and between the 10th and 13th days was $1.5 \mathrm{mgm}$. per $\mathrm{kgm}$., while the creatinine was $12.4 \mathrm{mgm}$. per $\mathrm{kgm}$. Unfortunately, the experiment was discontinued at this point.

Patient No. 2 had previously been stabilized on a daily dose of $96 \mathrm{mgm}$. of thyroid and had a fairly constant output of creatine, averaging 1.8 mgm. per kgm. with a creatinine excretion of 15.5 $\mathrm{mgm}$. per $\mathrm{kgm}$. Continuing the same dose of thyroid, the patient was given $30 \mathrm{mgm}$. methyl testosterone daily. During the first 12 days there was a slight decrease in the excretion of creatine and creatinine. After this, the excretion increased until on the 25th and 26th days the output was creatine $8.5 \mathrm{mgm}$. per $\mathrm{kgm}$. and creatinine 14.4 mgm. per kgm. At this time thyroid medication was discontinued but the administration of methyl testosterone was continued. After 2 days the excretion of creatine decreased abruptly and remained at levels between 0.8 and $2.0 \mathrm{mgm}$. per $\mathrm{kgm}$. between the 4th and 13th days. After the 13th day the output again increased reaching 9.7 mgm. per kgm. between the 16th and 18th days, and then continued to rise until between the 25th and 27 th days the output of creatine was $22.4 \mathrm{mgm}$. per $\mathrm{kgm}$. and that of creatinine $23.0 \mathrm{mgm}$. per $\mathrm{kgm}$. It should be noted that in this experiment the creatinuria due to methyl testosterone was on an ascending curve which had not yet reached a plateau. In the midst of this ascent the withdrawal of thyroid caused an abrupt decrease in the output of creatine which lasted for about 13 days. This was followed then by an increasing creatinuria which again followed the ascending curve to the high levels frequently observed under medication with methyl testosterone (compare Figure 3). The temporary decrease in creatine excretion must be attributed to the onset of thyroid deficiency brought about by withdrawing therapy, because it has never been observed while methyl testosterone was being administered to individuals who were not hypothyroid. The significance of this finding will be discussed later.

Summary: The various effects of thyroid hormone on the storage and excretion of creatine and creatinine are summarized in Table IV.

\section{DISCUSSION OF CREATINE METABOLISM}

In the studies presented above we have dealt entirely with the endogenous metabolism of creatine which has been shown to proceed independently of ingested creatine. The present theories on the relations of creatine in the body are illustrated in Figure 9.

TABLE IV

Summary of effects of thyroid on storage and excretion of creatine bodies

\begin{tabular}{l|c|c|c|c|c|c}
\hline & \multicolumn{3}{|c|}{ Muscle } & \multicolumn{2}{c}{ Urine } \\
\cline { 2 - 5 } & Creatine & Phospho-Cr. & Creatine & Creatinine & Total & Creatine per cent of total \\
\hline $\begin{array}{l}\text { Hyperthyroidism } \\
\text { Hypothyroidism }\end{array}$ & - & - & + & - & $\begin{array}{c}-? \\
+?\end{array}$ & $\begin{array}{c}30 \text { to } 60+ \\
0 \text { to } 6 \\
\text { (Normal 10 to 30) }\end{array}$ \\
\hline
\end{tabular}

Correction of hyperthyroidism-excretion of creatine and creatinine reversed toward normal Correction of hypothyroidism

\footnotetext{
(Urinary Excretion)

First phase Creatine ++++ Creatinine - Total +++ (lasting 30 to 60 days) Methyl testosterone in hypothyroid patient

Creatinine - Total unchanged or slightly -

1. Causes increased creatine synthesis and excretion as in normal patient

2. Withdrawal of M-T causes no temporary increase of excretion

Induction of hypothyroidism (discontinuing thyroid) in patient receiving methyl testosterone

Causes temporary decrease of creatinuria
} 
Creatine is synthesized by the combination of arginine and glycine to form glycocyamine which is methylated by some agent such as methionine or choline. New creatine is constantly formed to replace the urinary loss. of creatine and creatinine. In the muscle, creatine enters into a rapid equilibrium exchange with inorganic phosphate. The enzymatic reactions necessary for this cycle involve the formation of adenosine triphosphate and the oxidation of carbohydrates (6 to 8). The excretion of creatine is apparently influenced by factors different from those which govern the out- put of creatinine. It may vary markedly in the same individual, It is high in childhood, low in adult life. It is increased by starvation, high protein diet, carbohydrate deprivation, fevers, thyrotoxicosis and by the administration of methyl testosterone, and is decreased in hypothyroidism and by the administration of testosterone propionate. The complete absence of creatine from the urine at times may be due to the fact that there is a renal threshold so that it is excreted only when the serum concentration exceeds $0.58 \mathrm{mgm}$. per cent (35). In marked contrast the excretion of crea-

\section{THEORY A}

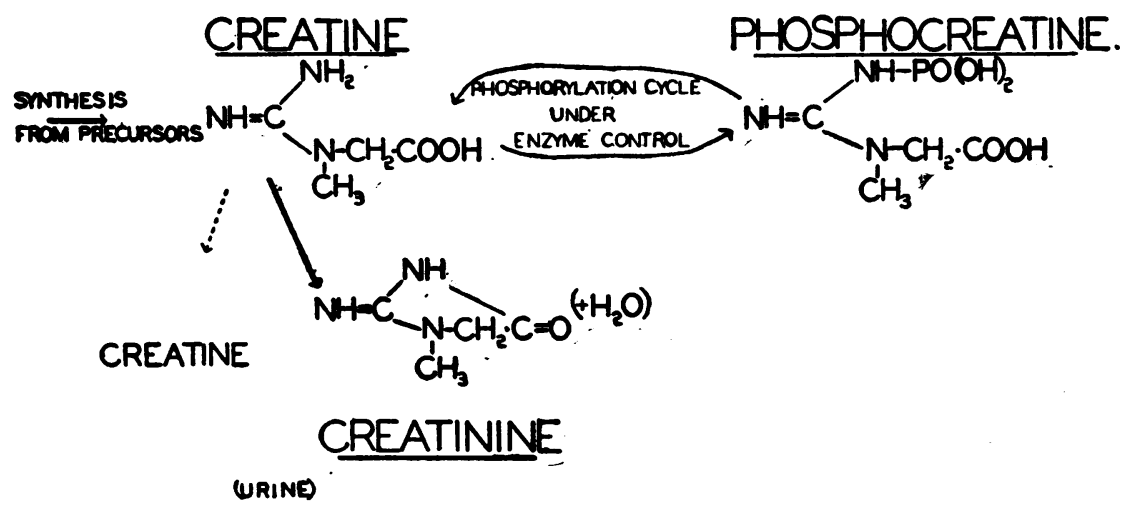

\section{THEORY B}

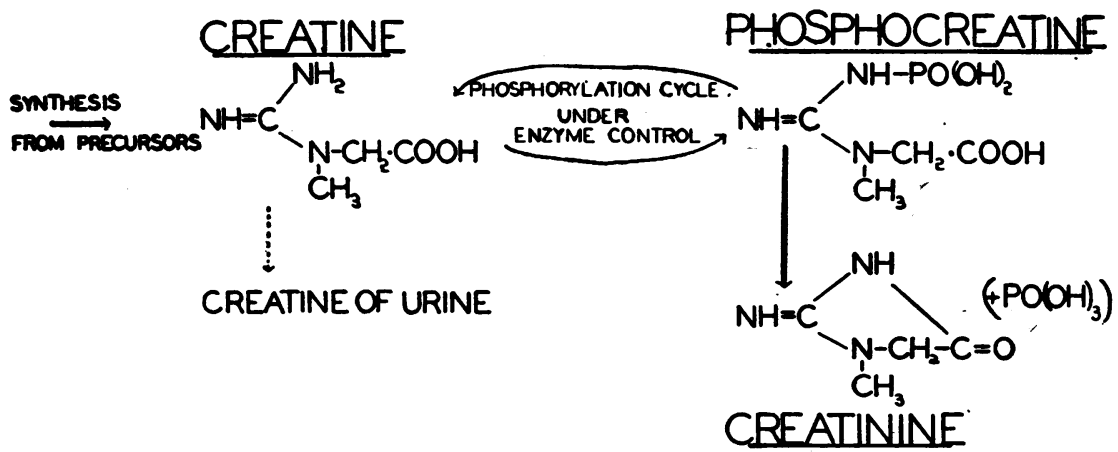

Fig. 9. Two Theories of Creatine-Creatinine Metabolism

Represents the liberation and excretion of creatine. This varies considerably depending upon the ability of the muscles to retain or liberate free creatine. If the amount liberated into the blood is below the renal threshold none appears in the urine.

Represents the formation and excretion of creatinine. The chemical reaction is believed to occur at a constant rate in which case the amount formed would depend upon the total stores of creatine or of phosphocreatine in the body. The excretion is not limited by a renal threshold. 
tinine is fairly constant for each individual. The relative stability of the output and the lack of effect of exercise and diet led originally to the concept that the total amount of creatinine excreted depended solely upon the total muscle mass of the body. The fact that changes sometimes occur which are greater than can be accounted for by alterations in the muscle mass makes it seem more probable that the creatinine output depends upon the total stores of creatine in the muscle which might be subject to variation, rather than upon the muscle mass. Bloch, Schoenheimer and Rittenberg (36) showed that the rate of excretion of creatinine corresponded to a conversion of 2 per cent of the creatine in the body in 24 hours. There is no renal threshold for creatinine.

It has been generally accepted that creatinine is derived from creatine by the removal of a molecule of water and the addition of a C-N linkage (Theory A. Figure 9). Recently a number of workers have suggested that creatinine might be formed by the dephosphorylation of phosphocreatine as shown in Theory B. Figure 9. Borsook and Dubnoff (37) found that in vitro at $38^{\circ} \mathrm{C}$. without the intervention of an enzyme, phosphocreatine breaks down to creatinine at the rate of 2 per cent in 24 hours, which is much faster than the formation of creatinine from creatine under the same conditions. Rosengart (38) working with minced muscle obtained similar results and Lipmann (8) suggested the same possibility. Wang (4) as a result of extensive clinical investigations, stated "the formation of creatinine may be somehow related to the amount of phosphocreatine present in the organism and not to the total creatine contents."

Taking the above facts into consideration, it is apparent that changes in the excretion of creatine or of creatinine might result from a number of different causes, namely:

\section{Changes in the rate of synthesis of creatine from its precursors}

It has been shown that the synthesis of creatine is increased by the administration of methyl testosterone $(13,14)$. Other conditions which might affect this synthesis have not been fully investigated.
2. Changes in the ability of the muscles to store or liberate creatine or phosphocreatine

Analyses of muscles have shown that the concentration of creatine is decreased in thyrotoxicosis $(4,26,27)$, in progressive muscular dystrophy $(39,44)$ and in denervation atrophy $(41)$. Wang (4) demonstrated increased creatine and phosphocreatine in the muscle of thyroidectomized rabbits, and Williamson and Gulick (42) found increased total creatine of muscle after the administration of testosterone propionate.

\section{Changes in the rate or direction of the creatine-} phosphocreatine cycle

Direct studies on the ways in which this reaction may be influenced are lacking. However, several workers $(43,4)$ have suggested that thyroid may have an influence on the synthesis or breakdown of phosphocreatine.

\section{Changes in the rate of conversion of creatine or of phosphocreatine into creatinine}

We are not aware of any direct evidence on this subject.

CONSIDERATION OF THE EFFECTS OF THYROID ON CREATINE METABOLISM

Does thyroid influence the rate of synthesis of creatine from its precursors?

The observations which we have recorded suggest that it has little, if any, influence. In the two hypothyroid patients studied (see Figure 6) methyl testosterone caused increased excretion of creatine irrespective of whether the condition was untreated or well controlled by thyroid therapy. Furthermore, treatment of hypothyroid patients with methyl testosterone caused an increased output of creatine + creatinine, whereas after the first phase of adjustment thyroid medication did not increase but possibly diminished the total output, although the ratio of the two compounds was altered (Figure 2).

\section{Does thyroid influence the storage of creatine?}

We have already discussed the evidence that the large amounts of creatine excreted during the first 30 to 35 days of thyroid medication by the four patients presented in Figure 2 were apparently due to the release of stores of muscle creatine. In normal individuals thyroid causes a simi- 
lar response, but larger doses are required and the losses of creatine are smaller and of shorter duration (31). We have reported (44) that thyrotropic hormone acts in the same way in most normal individuals.

When thyroid is withdrawn from the body increased amounts of creatine are apparently retained. This is suggested by the experiment (Figure 8 ) in which treated myxedematous patients were allowed to lapse into the hypothyroid state by withdrawing thyroid therapy while they continued to receive methyl testosterone. Even though the rates of synthesis and excretion of creatine were increased greatly above the normal by methyl testosterone, the withdrawal of thyroid apparently caused creatine to be retained to such a degree that little was excreted until after the 13 th day, when the storage capacity of the muscles again became filled to overflowing. Additional evidence that the hypothyroid patient retains creatine more tenaciously than the normal individual is afforded by the observation that when methyl testosterone was discontinued there was no release of a portion of the stored creatine such as occurs in the normal individual (Figure 7). These deductions concerning the effects of thyroid on the storage of creatine are substantiated by the careful chemical analyses of the muscles of rabbits by Wang (4) showing that in hypothyroidism the concentrations of creatine and phosphocreatine are increased and in hyperthyroidism they are diminished.

Little is known concerning the way in which thyroid governs the movements of creatine into or out of the muscles. It is possible that the loss of creatine which occurs when the hypothyroid patient is first treated may to some extent be accounted for by the breakdown of muscle tissue under the influence of thyroid. We have corroborated the observation of Maroney and Johnston (45) that the administration of thyroid to hypothyroid children results at first in a negative nitrogen balance which is then followed by a positive balance as the patient begins to grow and build new tissue. As shown in Figure 2 the periods of nitrogen deficit correspond roughly to those of creatine loss. However, the amount of muscle protoplasm catabolized calculated from our data ${ }^{2}$

\footnotetext{
2 Because of the variability of the fluid content of myxedematous muscles, only an approximate calculation
}

on the assumption that all the nitrogen loss comes from muscle tissue, is insufficient in some cases to yield the amounts of creatine + creatinine which were lost in these periods. Likewise it is difficult to believe that the increased stores of creatine which are accumulated when thyroid is withdrawn can be explained entirely by the building of new muscle protoplasm. Another possibility is that the movements of creatine may be associated to some extent with those of tissue fluid. This is suggested by the fact that the changes in creatine excretion and the loss or accumulation of myxedematous fluid are the earliest and most rapid effects observed when thyroid is given or withdrawn. They occur much more rapidly than changes in the B.M.R. More extensive study would be necessary to determine whether the movement of creatine into or out of muscle occurs independently or whether it is associated with changes in muscle protoplasm or tissue fluid.

\section{Does thyroid influence the rate of conversion of creatine into creatinine?}

Both our data and the studies of others offer convincing evidence that the amount of creatine which is converted into creatinine is decreased in hyperthyroidism and increased in hypothyroidism. It is not possible to explain the diminished output of creatinine caused by thyroid as the result of a decrease in the total muscle mass, because when a hypothyroid child is properly treated he stores nitrogen, grows and develops increased musculature while his creatinine output decreases. Likewise if the change in creatinine output were due to a catabolic effect of thyroid on the muscle tissue, one would expect the urinary creatinine to be high in hyperthyroidism, whereas actually it is low.

If the amount of creatinine formed daily depends solely upon the total stores of creatine or of phosphocreatine in the body, the changes in excretion observed might depend upon alterations in stores which are brought about by thyroid. Thyroid increases the output of creatine, thereby diminishing the stores in the muscles and hence the production of creatinine. Deficiency of thy-

can be made from the nitrogen losses of the amounts of creatine which might be liberated by the breakdown of muscle protoplasm. It is possible that in cases 2 and 4 , sufficient muscle was catabolized to yield the amounts of creatine lost, but this is not true in cases 1 and 3 . 
roid leads to increased stores in the muscle and accordingly increased production of creatinine. These alterations in the excretion of creatinine could occur irrespective of whether it is derived from creatine or phosphocreatine, because the stores of both creatine and phosphocreatine are increased or decreased simultaneously.

It is by no means certain that the changes in the muscle stores are of sufficient magnitude to account for the degree of alteration in the output of creatinine actually observed. In this case, it is necessary to assume that thyroid must in some way influence directly the conversion of creatine into creatinine. If creatinine is derived directly from creatine, this reaction must be directly affected. On the other hand, if creatinine is formed from phosphocreatine, thyroid might diminish the production of creatinine by influencing the enzyme system controlling the phosphorylation of creatine to phosphocreatine as suggested by Wang.

Our observations offer no solution to these problems but indicate the necessity of further investigations.

\section{SUMMARY AND CONCLUSIONS}

We have discussed the present knowledge of the metabolism of creatine especially in reference to the problems of storage and excretion, and have presented two theories concerning the origin of creatinine (Figure 9). It seems probable that alterations in the excretion of creatine bodies might be brought about by changes (1) in the rate of synthesis of creatine from its precursors; (2) in the ability of the muscles to store or to liberate creatine; (3) in the rate or direction of the creatine-phosphocreatine cycle; (4) in the rate of conversion of creatine or of phosphocreatine into creatinine.

Various studies of the effects of thyroid hormone on the storage and excretion of creatine and creatinine are reported and summarized in Table IV. Analysis of these observations suggests the following conclusions:

Thyroid has negligible effect upon the synthesis of creatine from its precursors. Its effect upon the excretion of creatine depends largely upon the fact that it facilitates the loss of creatine from the muscles. Excess of thyroid increases the amount of creatine liberated from the muscles, thereby decreasing the stores of creatine and phosphocreatine. In the absence of thyroid, creatine is retained in the muscle and the stores of both creatine and phosphocreatine are increased. When thyroid is administered to a patient with myxedema the amounts of creatine lost cannot, be accounted for entirely by the catabolism of muscle protoplasm. It is not known whether the movements of creatine into or out of muscle occur independently or are associated with changes in muscle protoplasm or of tissue fluid.

The fact that the output of creatinine is altered in the opposite direction from that of creatine might be explained solely by the changes of concentration of creatine and phosphocreatine in the muscles. However, it is not certain that the magnitude of the changes in concentration of the muscle stores is sufficient to account for the change in the excretion of creatinine actually observed. It is possible that in addition to diminishing the stores of creatine and phosphocreatine in the muscles, thyroid may also decrease the conversion of these substances into creatinine.

The methyl testosterone (Metandren) and the testosterone propionate (Perandren) were kindly supplied by the Ciba Pharmaceutical Products, Inc., Summit, N. J. Diets were planned by the dietary department of the Johns Hopkins Hospital. Misses Ilse A. Fried and Betty McDonnell assisted in the creatine determinations. We wish to thank Dr. Vincent du Vigneaud, of Cornell University Medical College, for reading and criticizing the manuscript. We are especially appreciative of the cooperation of Dr. George A. Johns and Dr. Isabel McClinton who enabled us to carry out part of the study on patient 2 at the Rosewood State Training School.

\section{BIBLIOGRAPHY}

1. Hunter, A., Creatine and Creatinine. Longmans, Greene Co., New York, 1928.

2. Rose, W. C., The metabolism of creatine and creatinine. Ann. Rev. Biochem., 1933, 2, 187.

3. Beard, H. H., Creatine and Creatinine Metabolism. Chemical Publishing Co., Inc., Brooklyn, 1943.

4. W.ang, E., Clinical and experimental investigations on the creatine metabolism. Acta med. Scandinav., 1939, suppl. 105, 1.

5. Eggleton, G. P., and Eggleton, $P$., The inorganic phosphate and a labile form of organic phosphate in the gastrocnemius of the frog. Biochem. J., 1927, 21, 190.

6. Fiske, C. H., and Subbarow, Y., The nature of the "inorganic phosphate" in voluntary muscle. Science, 1927, 65, 401. 
7. Needham, D. M., The biochemistry of muscle. Ann. Rev. Biochem., 1937, 6, 395.

8. Lipmann, F., Metabolic generation and utilization of phosphate bond energy. Advances Enzymol., 1941, 1, 99.

9. Bloch, K., and Schoenheimer, R., The biological precursors of creatine. J. Biol. Chem., 1941, 138, 167.

10. du Vigneaud, V., Cohn, M., Chandler, J. P., Schenck, J. R., and Simmonds, S., The utilization of the methyl group of methionine in the biological synthesis of choline and creatine. J. Biol. Chem., 1941, 140, 625.

11. Borsook, H., and Dubnoff, J. W., Synthesis of glycocyamine in rat kidney and mechanism of creatine synthesis in vivo. Science, 1940, 91, 551.

12. Wilkins, L., Fleischmann, W., and Howard, J. E., Creatinuria induced by methyl testosterone in the treatment of dwarfed boys and girls. Bull. Johns Hopkins Hosp., 1941, 69, 493.

13. Wilkins, L., and Fleischmann, W., Studies on the creatinuria due to methylated steroids. J. Clin. Invest., 1945, 24, 21.

14. Samuels, L. T., Henschel, A. F., and Keys, A., Influence of methyl testosterone on muscular work and creatine metabolism in normal young men. J. Clin. Endocrinol., 1942, 2, 649.

15. Shaffer, P. A., The excretion of kreatinin and kreatin in health and disease. Am. J. Physiol., 1908, 23, 1.

16. Palmer, W. W., Carson, D. A., and Sloan, L. W., The inflience of iodine on the excretion of creatine in exophthalmic goiter. J. Clin. Invest., 1929, 6; 597.

17. Shorr, E., Richardson, H. B., and Wolff, H. G., The nature of the muscular weakness in Graves' disease. J. Clin. Invest., 1933, 12, 966.

18. Richardson, H. B., and Shorr, E., The creatin metabolism in atypical Graves' disease. Tr. A. Am. Physicians, 1935, 50, 156.

19. McCrudden, F. H., The effect of fat and of carbohydrate diets on the excretion of creatine in cases of retarded development. J. Exper. Med., 1912, 15, 457.

20. Beumer, H., and Iseke, C., Der Kreatin-Kreatininstoffwechsel bei Myxödem und Gesunden unter Einwirkung von Thyreoidin. Berlin. Klin. Wchnschr., 1920, 57, 178.

21. Poncher, H. G., Bronstein, I. P., Wade, H. W., and Ricewasser, J. C., Creatine metabolism in hypothyroid infants and children. Further observations. Am. J. Dis. Child., 1942, 63, 270.

22. Hess, J., Blood cholesterol and creatine excretion in urine as aids to diagnosis and treatment of hypothyroidism. Ann. Int. Med., 1934, 8, 607.

23. Langmann, A. G., and Bruch, H., Carcinoma of the thyroid in children. Report of a case associated with multiple anomalies of development, with studies of basal metabolism, serum cholesterol and creatine excretion after thyroidectomy. Am. J. Dis. Child., 1938, 56, 616.
24. Feldmann, L., and Wilhelm, A., Ueber die Kreatininausscheidung bei Basedowkranken. Med. Klin., 1927, 23, 1856.

25. Eimer, K., Studien über den Kreatin- Kreatininstoffwechsel. III. Beziehungen der Kreatinkörperausscheidung zu Stoff wechsel und Schilddrüsenfunktion. Ztschr. f. d. ges. exper. Med., 1931, 77, 455.

26. Abelin, J., and Spichtin, W., Ueber den Einfluss der Schilddrüsensubstanzen auf den Gesamtkreatiningehalt der Leber und des Muskels. Biochem. Ztschr., 1930, 228, 250.

27. Bodansky, M., Pilcher, J. F., and Duff, V. B., Concerning the relation of environmental temperature to resistance to thyroid and thyroxine and the creatine content of the heart and other tissues in experimental hyperthyroidism. J. Exper. Med., 1936, 63, 523.

28. Kepler, E. J., and Boothby, W. M., Creatinuria in hyperthyroidism. Am. J. M. Sc., 1931, 182, 476.

29. Sloan, M. H., and Shorr, E., Metabolic effects of thiouracil in Graves' disease. Science, 1944, 99, 305.

30. Shorr, E., Minutes of Conference on Metabolic Aspects of Convalescence including Wound and Bone Healing, June, 1944.

31. Wilkins, L., Fleischmann, W., and Block, W., Hypothyroidism in childhood. II. Sensitivity to thyroid medication as measured by the serum cholesterol and the creatine excretion. J. Clin. Endocrinol., $1941,1,14$.

32. Shorr, E., Richardson, H. B., and Mansfield, J. S., Influence of thyroid administration on creatin metabolism in myxedema of adults. Proc. Soc. Exper. Biol. and Med., 1935, 32, 1340.

33. Fan, C., Creatine and creatinine metabolism in hypothyroidism. J. Pediat., 1941, 18, 57.

34. Kenyon, A. T., Knowlton, K., and Sandiford, I., The anabolic effects of the androgens and somatic growth in man. Ann. Int. Med., 1944, 20, 632.

35. Tierney, N. A., and Peters, J. P., The mode of excretion of creatine and creatine metabolism in thyroid disease. J. Clin. Invest., 1943, 22, 595.

36. Bloch, K., Schoenheimer, R., and Rittenberg, D., Rate of formation and disappearance of body creatine in normal animals. J. Biol. Chem., 1941, 138, 155.

37. Borsook, H., and Dubnoff, J. W., The metabolism of proteins and amino acids. Ann. Rev. Biochem., 1943, 12, 183.

38. Rosengart, V., Formation of creatinine in the animal body. Nature, 1944, 154, 829.

39. Nevin, S., Study of muscle chemistry in myasthenia gravis, pseudohypertrophic muscular dystrophy and myotonia. Brain, 1934, 57, 239.

40. Reinhold, J. G., and Kingsley, G. R., Chemical composition of voluntary muscle in muscle disease: comparison of progressive muscular dystrophy with 
other diseases together with study of effects of glycine and creatine therapy. J. Clin. Invest., 1938, 17, 377.

41. Tower, S. S., The reaction of muscle to denervation. Physiol. Rev., 1939, 19, 1.

42. Williamson, M., and Gulick, A., Influence of testosterone on distribution and excretion of creatine. Endocrinology, 1941, 28, 654.

43. Shorr, E., Richardson, H. B., and Wolff, H. G., Endogenous glycine formation in myopathies and
Graves' disease. Proc. Soc. Exper. Biol. and Med., 1933, 31, 207.

44. Wilkins, L., and Fleischmann, W., Hypothyroidism in children. IV. The creatine and cholesterol response to thyrotropic hormone. J. Clin. Endocrinol., 1941, 1, 98.

45. Johnston, J. A., and Maroney, J. W., Factors affecting retention of nitrogen and calcium in period of growth. I. Effect of thyroid on nitrogen retention. Am. J. Dis. Child., 1939, 58, 1965. 